\title{
Immobilization of Lipases Produced by the Endophytic Fungus Cercospora kikuchii on Chitosan Microparticles
}

\author{
Lara Aparecida Buffoni Campos Carneiro ${ }^{1}$, Tales Alexandre Costa-Silva ${ }^{1}$, Cláudia Regina \\ Fernandes Souza ${ }^{1}$, Luciano Bachmann ${ }^{2}$, Wanderley Pereira Oliveira ${ }^{1}$ and Suraia Said ${ }^{1 *}$ \\ ${ }^{I}$ Departamento de Ciências Farmacêuticas; Faculdade de Ciências Farmacêuticas de Ribeirão Preto; Universidade \\ de São Paulo; Ribeirão Preto - SP - Brasil. ${ }^{2}$ Departamento de Física; Faculdade de Filosofia, Ciências e Letras de \\ Ribeirão Preto; Universidade de São Paulo; Ribeirão Preto - SP - Brasil
}

\begin{abstract}
This work studied the immobilization of Cercospora kikuchii lipases on chitosan microparticles by chemical attachment on chitosan acetate microparticles activated by glutaraldehyde (CAM) added before or after the enzyme and physical adsorption on highly deacetylated chitosan hydrochloride microparticles (CHM). Lipases covalently immobilized on pre-activated CAM showed better performance retaining $88.4 \%$ of the enzymatic activity, with $68.2 \%$ of immobilization efficiency (IE). The immobilized enzyme retained an activity of about $53.5 \%$ after five reuses, using p-NPP as substrate. Physical adsorption of lipase onto highly deacetylated CHM showed $46.2 \%$ of enzymatic activity and $28.6 \%$ of IE. This immobilized derivative did not lose activity up to 80 days of storage at $4{ }^{\circ} \mathrm{C}$, while lipases immobilized on pre-activated CAM maintained its activity up to 180 days at same conditions. Taken together the results indicate that chitosan microparticles provide an optimal microenvironment for the immobilized enzyme to maintain good activity and stability.
\end{abstract}

Key words: enzyme immobilization, chitosan, Cercospora kikuchii, lipase

\section{INTRODUCTION}

Lipases (triacylglycerol acylhydrolases E.C.3.1.1.3) are enzymes that catalyze the total or partial hydrolysis of triacylglycerols, releasing diacylglycerols, monoacylglycerols, glycerol and free fatty acids. The wide industrial application of lipases extend from the food sector such as dairy, beverages, oil processing, meat and fish processing, up to the chemical sector in ester synthesis, production of detergents, and in cosmetics. The lipases also have potential use in biodiesel transesterification (Castro et al. 2004).

Lipases from microorganisms are widely used in these industrial processes. They are easily isolated from the fermentation broths and have higher stability and more diversified properties than lipases from other sources (Borgston and Brockman 1984; Castro and Anderson 1995). However, its inability of reuse and high cost of single use limit its use in industrial production. Besides, the activity of soluble enzymes is controlled by several parameters such as aggregation, autolysis, or proteolysis by proteases during catalysis. In recent years, enzyme immobilization technology has provided an effective method to circumvent these issues, due to the physical stability, which is needed to maintain the intrinsic enzyme structure. Enzyme immobilization not only improves its catalytic properties and operational stability but also facilitates enzymes multiple reuse, separation, and

*Author for correspondence: susaid@fcfrp.usp.br 
continuously automatic operation in industrial production (Polshettiwar and Asefa 2013; Zhang et al. 2013).

Many microorganisms have been reported as lipase producers, but because of the recent interest in the application of this enzyme in new industrial processes such as resolution of chiral drugs, fat modification and for synthesis of personal care products and flavor enhancers, new strains from different sources and with specific characteristics are being isolated (Deive et al. 2009; Dadavate et al. 2009; Bussamara et al. 2010). Endophytic fungi have also drawn attention as potential producers of many products, including industrially interesting enzymes. Endophytic fungi exhibit a complex web of interactions with the host plants and have been extensively studied over the last several years as prolific sources of new bioactive natural products, including new enzymes with interesting properties for industrial application (Verza et al. 2009; Borges et al. 2009; Fernandes et al. 2009). However, very few endophytic fungi have been reported as producers of lipase.

Different supports and methods have been used to immobilize fungal lipases with results of activity retention varying between 30 and $61 \%$ (Kim et al. 2006; Simões et al. 2011; Liu et al. 2011; Zhu and
Sun 2012). Chitosan is a biopolymer derived from crustacean skeleton chitin and commonly used as support (Biró et al. 2008). The features of chitin and chitosan include its abundance as a by-product of the fishing and fermentation industries, its low cost over other supports for enzymes, its lack of toxicity emphasized by the fact that chitin is present in the foods of large consumption such as shellfish and sake, its chemical reactivity allowing easy fixation of enzymes. The structure of chitin relates a polymer in which N-acetyl-D-glucosamine units prevail over the glucosamine units, while the chitosan is a polymer where D-glucosamine is the prevailing recurring unit in the chain (Muzzarelli 1980). The residues of these linear polymers are joined by $(\beta 1 \rightarrow 4)$ linkages (Fig. 1). The ratio between these units along the polymeric chain depends on the conditions used in the deacetylation process (Muzzarelli and Peter 1997). Chitosan amino groups are functional groups commonly used for the anchoring a large variety of molecules, including enzymes with or without crosslinker.

The present study aimed to explore different strategies to immobilize lipases from the endophytic fungus Cercospora kikuchii onto chitosan microparticles.
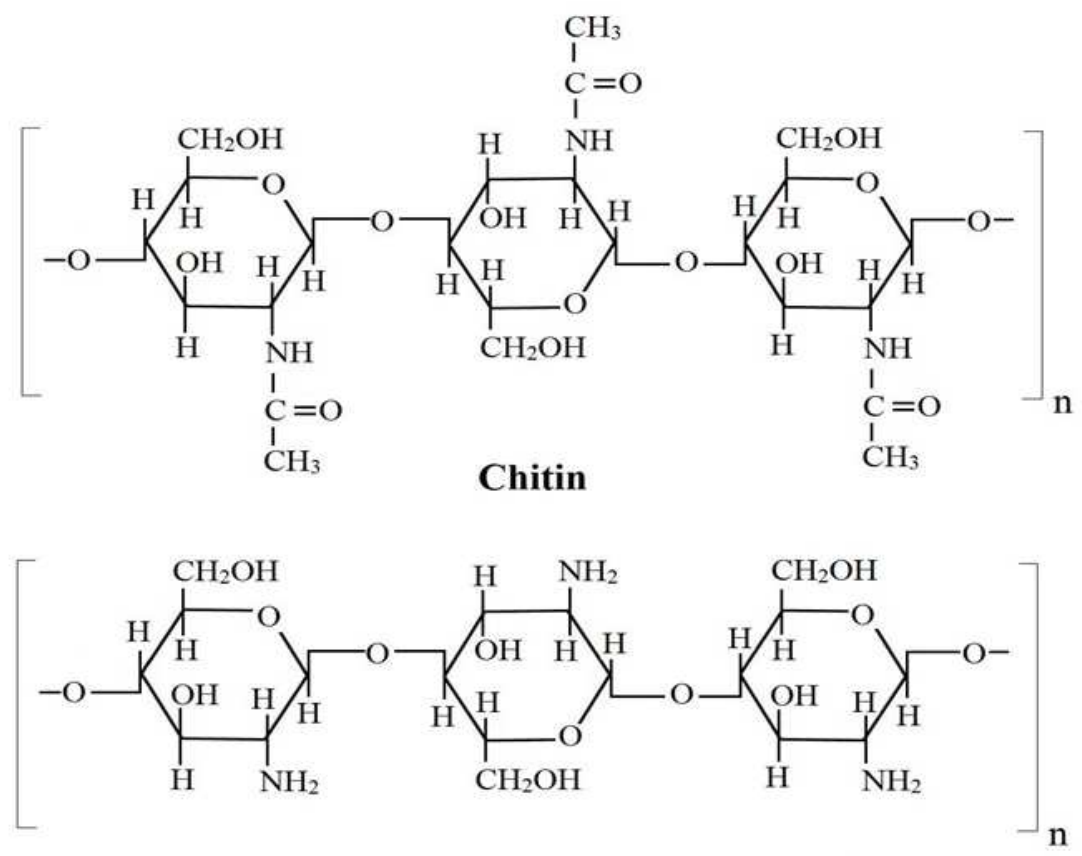

\section{Chitosan}

Figure 1 - Segments of chitin and chitosan polymers. Chitin is represented by N-acetyl-D-glucosamine units joined by $(\beta 1 \rightarrow 4)$ linkages and chitosan, by D-glucosamine residues in $(\beta 1 \rightarrow 4)$ linkages. 


\section{MATERIALS AND METHODS}

\section{Microorganism and Lipase Production}

Cercospora kikuchii was grown and maintained on potato dextrose agar (PDA) medium as previously reported by Costa-Silva et al. (2011). For lipase production, the fungus was cultivated on PDA medium at $30^{\circ} \mathrm{C}$ for seven days. Agar pieces $\left(1 \mathrm{~cm}^{2}\right)$ containing mycelium were inoculated on Vogel's minimum medium (Vogel 1956) supplemented with $2 \%$ soybean oil and incubated at $30^{\circ} \mathrm{C}$ in a rotatory shaker at $120 \mathrm{rpm}$ for six days. The culture broth containing extracellular lipases was filtered, dialyzed and concentrated and used in the immobilization process (Costa-Silva et al. 2011).

\section{Lipase Immobilization}

Lipases from $C$. kikuchii were immobilized on chitosan microparticles by chemical attachment on glutaraldehyde-treated chitosan acetate microparticles (CAM) and physical adsorption to highly deacetylated chitosan hydrochloride microparticles (CHM).

\section{Chemical Attachment of Lipase on CAM}

Two methods were used. Method 1: A suspension $(400 \mathrm{~mL})$ of $2 \%(\mathrm{w} / \mathrm{v})$ chitosan (Polymer, Amherst, MA) in $1.0 \%$ (w/v) acetic acid was prepared by stirring at $7930 \mathrm{xg}$ for $30 \mathrm{~min}$. After the addition of the enzyme solution to a final concentration of $500 \mathrm{U} / \mathrm{g}$ chitosan, the mixture was stirred to complete the homogenization. The procedure was completed by the addition of 13.2 $\mathrm{mL}$ of $2.5 \% \quad(\mathrm{w} / \mathrm{v})$ glutaraldehyde (Sigma Chemical Company, St. Louis, MO) and by stirring for $15 \mathrm{~min}$ more. The suspension (acetate microparticles with immobilized lipase) was dried at $160^{\circ} \mathrm{C}$ and atomized (Costa-Silva et al. 2010). Method 2: Lipases were immobilized according to Rorrer and Hsien (1993) with some modifications. Briefly, a suspension of powdered chitosan ( $4.0 \mathrm{~g})$ in $5 \%$ acetic acid $(96 \mathrm{~mL})$ was gently dropped into $1 \mathrm{M} \mathrm{NaOH}$ solution and stirred at $25^{\circ} \mathrm{C}$ for $24 \mathrm{~h}$. The acetylated product was washed with an excess of distilled water until neutral $\mathrm{pH}$ (Kimura et al. 1999) and dehydrated by lyophilization. For glutaraldehyde activation, the chitosan beads were added to $50 \mathrm{~mm}$ sodium phosphate buffer, $\mathrm{pH} 6.5$ (buffer 1) containing $2.5 \%(\mathrm{v} / \mathrm{v})$ glutaraldehyde and incubated at $25^{\circ} \mathrm{C}$ for $1 \mathrm{~h}$. Excess reagent was removed by washing with distilled water. Dried beads were used for lipase immobilization by covalent binding. Chitosan (2.5 g), previously activated as described, was mixed with aqueous lipase solution $(50 \mathrm{~mL}, 125 \mathrm{U} / \mathrm{g}$ of chitosan) under agitation at $25^{\circ} \mathrm{C}$ for $1 \mathrm{~h}$. The derivative was filtered, thoroughly rinsed with buffer 1 and lyophilized.

\section{Physical Adsorption of Lipase to CHM}

Chitosan $(1.0 \mathrm{~g})$ was suspended in $0.05 \mathrm{M} \mathrm{HCl}$ $(150 \mathrm{~mL})$ and the mixture was kept under gentle stirring for $24 \mathrm{~h}$. After the addition of $0.2 \mathrm{M} \mathrm{NaCl}$ $(150 \mathrm{~mL})$ the suspension was vacuum filtered through a porous membrane $(0.20 \mu \mathrm{m})$ (Signini and Campana Filho 2001). The filtrate was slowly mixed with absolute ethanol until precipitation and the suspension was centrifuged at $5800 \mathrm{xg}$ for 10 min. Both the supernatant (CHMS) and the precipitated (CHMP) were dried at room temperature. Lipase $(7.0 \mathrm{~mL})$ and $100 \mathrm{mg}$ of dried CHMS were mixed and kept under stirring at 2600 $\mathrm{xg}$ for $3 \mathrm{~h}$ at room temperature. The mixture was centrifuged at $4000 \mathrm{xg}$ for $5 \mathrm{~min}$ and the pellet washed three times with $2.0 \mathrm{~mL}$ of buffer 1 and again centrifuged as above until no activity was detected in the supernatant. Microparticles without lipases underwent the same washes for infrared analyses. The final pellet obtained was suspended with $10 \mathrm{~mL}$ of buffer 1 and lyophilized. Protein content was evaluated in each supernatant.

\section{Lipase Assay}

Lipase activity assay was performed using $\rho$ nitrophenyl palmitate ( $p$ NPP) as substrate according to Mayordomo et al. (2000) with few modifications. In brief, the reaction mixture consisted of $205 \mu \mathrm{L}$ of buffer (200 mg of Triton $\mathrm{X}-100$ and $50 \mathrm{mg}$ of gum arabic in $50 \mathrm{~mL}$ of 50 mm phosphate buffer, $\mathrm{pH} 6.5$ ), $45 \mu \mathrm{L}$ of substrate (15 mg of $p$ NPP in $10 \mathrm{~mL}$ of 2-propanol), and 250 $\mu \mathrm{L}$ of enzyme solution. The mixture was incubated at $40^{\circ} \mathrm{C}$ for $30 \mathrm{~min}$ and then $0.5 \mathrm{~mL}$ of $2 \%$ trizma base was added. The optical density was measured at $410 \mathrm{~nm}$. One unit (U) of lipase activity was the amount of enzyme that released $1 \mu \mathrm{mol}$ of $p$ nitrophenol/min under the assay conditions. The operational stability of immobilized derivatives too was determined using $p$ NPP as the substrate.

The immobilization efficiency, IE (\%), was determined by equation 1 (Menoncin et al. 2009), where $\mathrm{P}_{0}$ was the protein content in the lipase solution $(\mathrm{mg})$ and $\mathrm{P}_{1}$ was the amount of protein adsorbed on the chitosan microparticles $(\mathrm{mg}) . \mathrm{P}_{1}$ was estimated by the difference between total 
protein content offered to immobilization process and the protein content washed from the microparticles.

The activity retention (AR \%) was calculated following equation 2 (Kaewthong et al. 2005). $\operatorname{IE}(\%)=100 \times\left(\mathrm{P}_{0} / \mathrm{P}_{1}\right)$

$\mathrm{AR}(\%)=100 \mathrm{x}$ [Immobilized enzyme activity (U/mg) / Soluble enzyme activity (U/mg)]

\section{Protein Assay}

Protein concentrations were determined by the Bradford method (Bradford 1976) with bovine serum albumin (Sigma Chemical Company, St. Louis, MO) as a standard.

\section{Morphological Characterization of chitosan microparticles}

Analysis of the shape and surface characteristics of the microspheres was performed by scanning electron microscopy (SEM; JEOL, JSM 5200 model), with $1000 \mathrm{x}$ of magnification. Powdered samples were mounted for observation on a double-coated, stub adhered, conductive carbon tape.

\section{Infrared Spectroscopy}

Fourier Transform Infrared (FTIR) spectroscopy was employed for the analysis of chitosan samples (CHMS, CHMP, pre-activated CAM, and commercial chitosan). For this, the samples were covered a diamond crystal in an ATR (Attenuated Total Reflectance) accessory coupled to a FTIR spectrometer (Nicolet 380, Thermo Fisher Scientific Inc, USA). The degree of deacetylation was evaluated using the ratios of band intensities between $1560 \mathrm{~cm}^{-1}$ and $2920 \mathrm{~cm}^{-1}$. Band intensities were determined after background removal using adjacent minima or valleys near each band.

\section{RESULTS AND DISCUSSION}

One of the properties that generally improve due to immobilization is enzyme stability, under both storage and operational conditions (Mateo et al. 2007). Their physicochemical properties are often significantly modified compared to the corresponding enzyme in free solution. A significant advantage of immobilized enzyme is the increase of its thermal stability, allowing their use for longer periods at higher temperatures. Also, interesting and valuable are the changes in the pH-activity curves that often accompany immobilization. Improvement of selectivity and specificity may be achieved in certain cases too (Mateo et al. 2007).

\section{Chemical Attachment of Lipase onto CAM.}

Lipase immobilized on glutaraldehyde preactivated CAM (method 2) (Fig. 2) showed higher activity retention than the immobilized derivative from the method 1 in which the crosslinker was added after adsorption of the enzyme by the chitosan acetate microparticles. In this condition, only $0.1 \%$ of free enzyme activity was recovered on the support (Table 1). Concerning immobilized lipases, strategies for reactivation should regenerate not only the catalytic site of the lipase, but also the mechanism of opening and closing of the molecule (Betancor et al. 2006). Hence, low activity retention of lipases immobilized onto chitosan acetate microparticles by method 1 could be due to binding of key amino acids of lipase protein by glutaraldehyde, which hindered the conformational changes required for enzymatic activity. In addition, acid $\mathrm{pH}$ might also have a negative impact in enzyme activity.

In contrast, in the pre-activated support the activity retention was about $88 \%$ (Table 1), likely due to glutaraldehyde crosslinkages as amineglutaraldehyde-amine, amine-glutaraldehydeglutaraldehyde-amine, or amine(glutaraldehyde),-amine (Fernandez-Lafuente et al. 1995). It seemed that glutaraldehyde activation originated dimmers that conferred hydrophobicity to the support surface, and thus improved the retention of lipases with affinity for hydrophobic regions (Barbosa et al. 2012). This characteristic may have a positive impact in the immobilization process due to catalytic mechanism of lipases socalled interfacial activation (Verger 1997). Thus, the hydrophobic nature of glutaraldehyde may have permitted the adsorption of lipases via this mechanism, before the covalent attachment could take place (Barbosa et al. 2012).

Table 1 - Comparison between the methods applied for immobilization of lipases produced by endophytic fungus $C$. Kikuchii on chitosan microparticles.

\begin{tabular}{lccc}
\hline Technique & Support & AR (\%) & IE (\%) \\
\hline $\begin{array}{l}\text { Chemical } \\
\text { attachment }\end{array}$ & $\begin{array}{c}\text { Method 1 } \\
\text { CAM - }\end{array}$ & $0.10 \pm 0$ & $13.5 \pm 0.14$ \\
$\begin{array}{c}\text { Method 2 } \\
\text { Physical } \\
\text { adsorption }\end{array}$ & CHMS & $46.40 \pm 1.23$ & $68.20 \pm 1.86$ \\
\hline
\end{tabular}




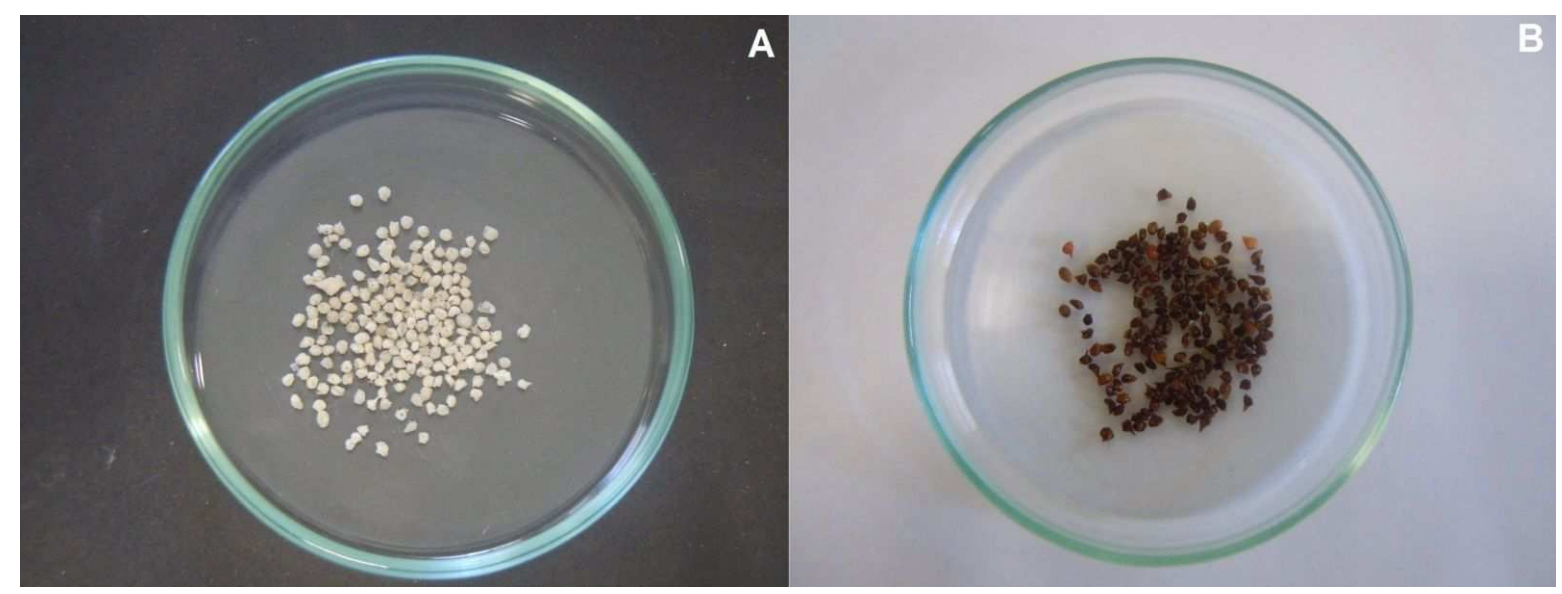

Figure 2 - CAM. A) After drying by lyophilization; B) after activation with glutaraldehyde.

The possibility to reuse the biocatalyst is of practical and economic importance in industrial applications. The CAM immobilized derivative obtained by the method 2 retained about $54 \%$ of enzyme activity after five reuses using p-NPP as substrate (Fig. 3). The stability of the immobilized derivatives produced by method 2 was determined during the storage period. Shelf-life of the product maintaining activity was six months at $4^{\circ} \mathrm{C}$ (Fig. 4) with only $3.3 \%$ of loss in enzymatic activity, whereas the free form of the enzyme lost $85.8 \%$ of its initial activity in the same period (Costa-Silva et al. 2013). These data were indicator of the viability of using the chitosan as support and the covalent binding as a way to protect the enzyme properties and control their stability.

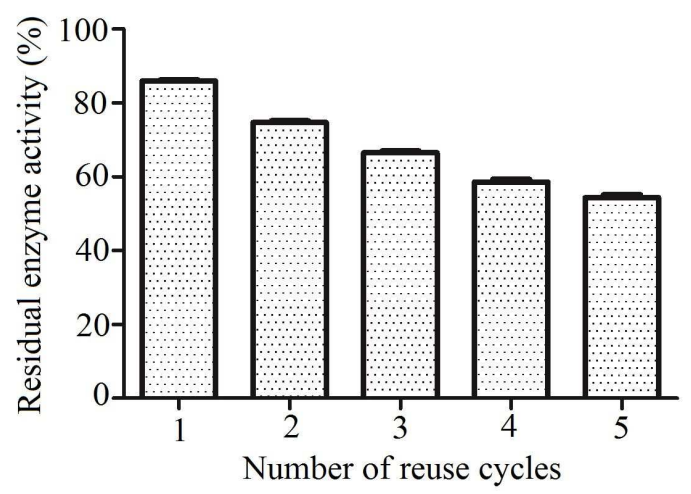

Figure 3 - Operational stability of CAM immobilized derivative (method 2 ) after reuse cycles.

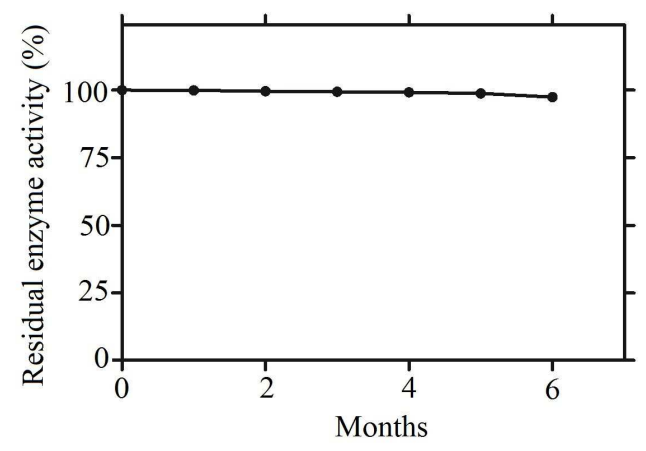

Figure 4 - Stability of CAM immobilized derivative (method 2) under storage at $4{ }^{\circ} \mathrm{C}$.

Scanning Electronic Microscopy (SEM) of particles obtained by the method 2 showed a grooved surface in an undefined format (Fig. 5). Fissures and pores can facilitate the fixation of the enzyme on the support originating an immobilized derivative with high activity. The efficiency of method 2 with respect to the incorporation of lipase was also assessed by Fourier Transform Infrared (FTIR) spectroscopy. Figure 6 shows the spectra for free lipase, pre-activated CAM, and immobilized derivative. Characteristic bands of free lipase clearly shown at $1341 \mathrm{~cm}^{-1}$ were also observed in the immobilized derivative (preactivated CAM + lipase) spectra, suggesting fixation of the enzyme to the support after the immobilization process. 


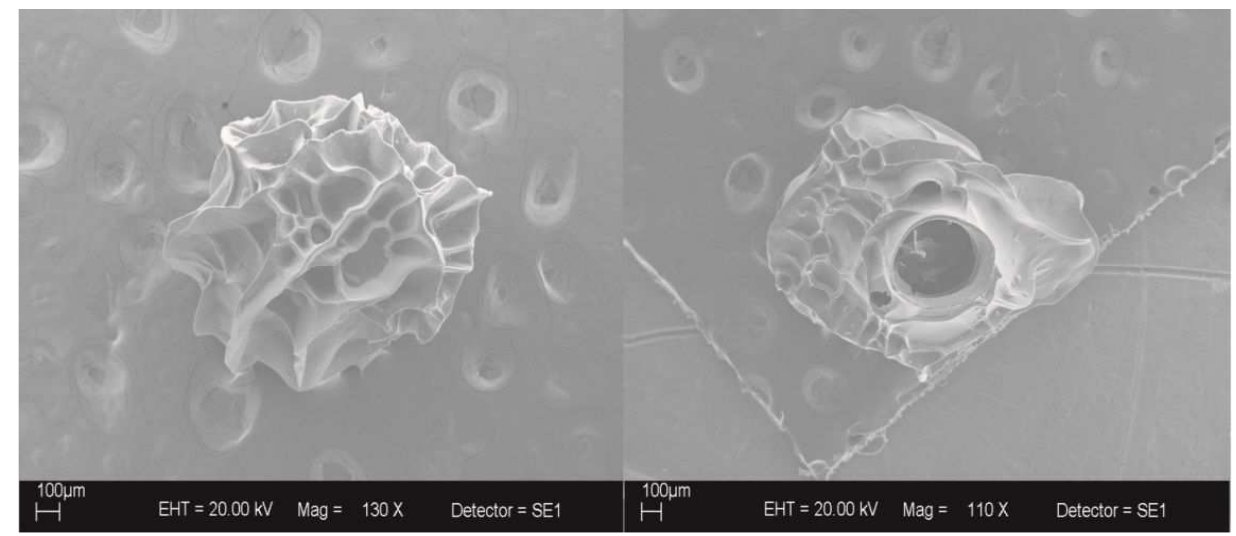

Figure 5 - Scanning electron photomicrographs of pre-activated CAM.

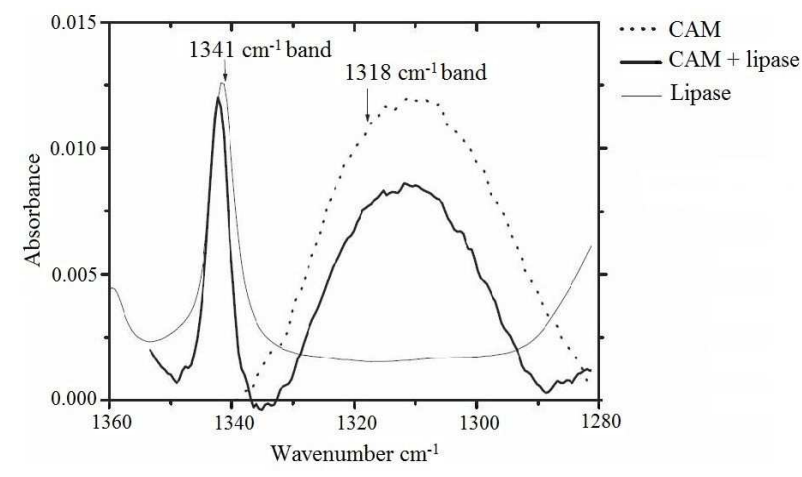

Figure 6 - FTIR spectra for free lipase, glutaraldehydepre-activated CAM and immobilized derivative $(\mathrm{CAM}+$ lipase $)$.

\section{Physical Adsorption of Lipase on CHMS}

As described in the methods, both the supernatant (CHMS) and the precipitated (CHMP) from the $\mathrm{CHM}$ suspension were dried at room temperature (Fig. 7). The deacetylation of CHMS and CHMP were evaluated by FTIR spectroscopy (Fig. 8), using the ratio $A_{\left(1560 \mathrm{~cm}^{-1}\right)} / \mathrm{A}_{\left(2920 \mathrm{~cm}^{-1}\right)}$ in the IR spectra to calibrate the chitosan deacetylation degree. According to Dong et al. (2001), the intensity of the $1560 \mathrm{~cm}^{-1}$ band of spectrum decreases with the chitosan deacetylation, becoming very weak for highly deacetylated specimens because of the increase of the intensity of the $1600 \mathrm{~cm}^{-1}$ band and the ratio $A_{(1560)} / A_{(2920)}$ from IR spectra is suitable to infer about the chitosan deacetylation degree. Lipases immobilized on CHMS retained $46.2 \%$ of activity (Table 1). FTIR spectroscopy indicated higher deacetylation of CHMS when compared to CHMP (Table 2), which could have contributed to successful immobilization of lipases on that support. The degree of deacetylation affects the functional and sorption properties of chitosan through exposure of its amino groups available for interactions with the enzyme (Orrego and Valencia 2009), including low-energy interactions such as van der Waals, ionic and hydrogen bonds. The treatments of commercial chitosan that included $\mathrm{HCl} 0.05 \mathrm{M}, \mathrm{NaCl} 0.2 \mathrm{M}$ and ethanol might have promoted breakdown of O-glycosidic bonds, thus contributing to the high deacetylation of chitosan in CHMS.

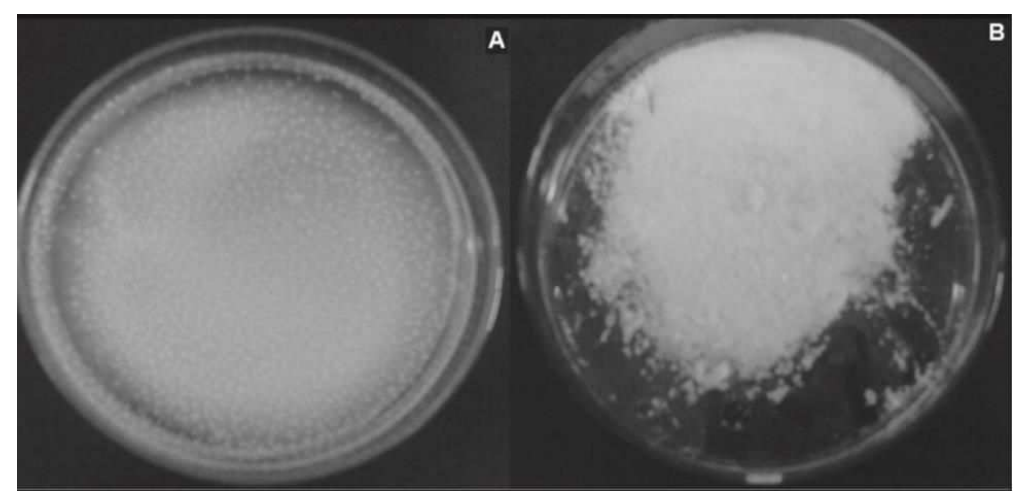

Figure 7 - CHMS. A) After drying at room temperature; B) after scraping dried microparticles from the plate. 


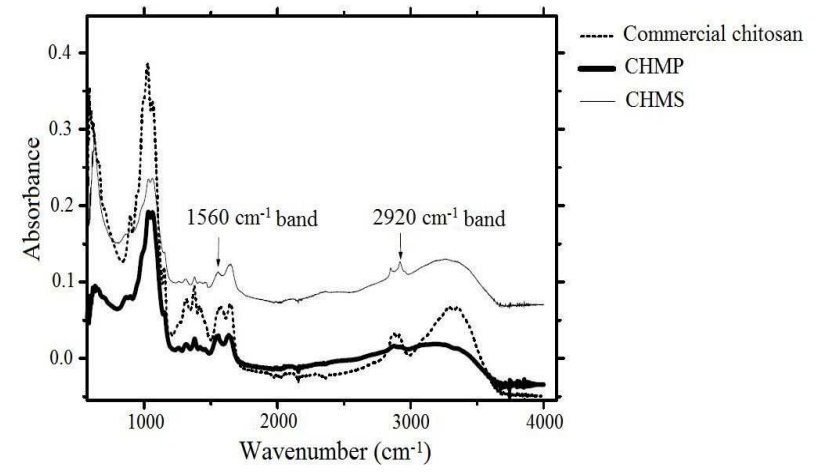

Figure 8 - FTIR spectra of CHMS, CHMP and commercial chitosan.

Table 2 - Absorbances of $1560 \mathrm{~cm}^{-1}$ band relative to $2920 \mathrm{~cm}^{-1}$ band of CHMS, CHMP and commercial chitosan.

\begin{tabular}{lccc}
\hline & CHMS & $\begin{array}{c}\text { Commercial } \\
\text { chitosan }\end{array}$ & CHMP \\
\hline $\mathrm{A}_{\left(1560 \mathrm{~cm}^{-1}\right)}$ & 0.0175 & 0.0436 & 0.0250 \\
$\mathrm{~A}_{\left(2920 \mathrm{~cm}^{-1}\right)}$ & 0.0210 & 0.0296 & 0.0076 \\
$\mathrm{~A}_{\left(1560 \mathrm{~cm}^{-1}\right)} /$ & 0.833 & 1,473 & 3,290 \\
$\mathrm{~A}_{\left(2920 \mathrm{~cm}^{-1}\right)}$ & & & \\
\hline
\end{tabular}

In order to obtain the $\mathrm{A}_{\left(1560 \mathrm{~cm}^{-1}\right)}$ and $\mathrm{A}_{\left(2920 \mathrm{~cm}^{-1}\right)}$ values, the baseline absorbance value was subtracted from the absorbance at $1560 \mathrm{~cm}^{-1}$ or $2920 \mathrm{~cm}^{-1}$ band.
Scanning electron photomicrographs of CHMS showed sizes varying from 8 to $80 \mu \mathrm{m}$ with a deeply porous surface (Fig. 9), which allowed for a wide surface area available for immobilization, maximizing the amount of protein immobilized. This could have contributed to the large storage stability of lyophilized lipase immobilized on highly deacetylated CHMS that was stored with no loss of activity up to 80 days at $4^{\circ} \mathrm{C}$ (Fig. 10). The larger surface area as a result of the micro/nanostructure of the materials could be the reason for better substrate-enzyme interaction, owing in part to a higher number of active sites exposed to the media. Indeed, enzyme activity is strongly dependent on the three-dimensional (3D) structure of the enzyme molecules because the active site should be conserved in order for the catalytic reaction between and enzyme and its substrate to occur (Polshettiwar and Asefa 2013). Vertegel et al. (2004) studied whether particle size contributed to protein 3D structure preservationand found a greater loss of enzyme activity for lysozyme immobilized onto $100 \mathrm{~nm}$ $\mathrm{SiO}_{2}$ when compared with the same enzyme immobilized on $4 \mathrm{~nm}$ and $20 \mathrm{~nm}$ nanoparticles (Polshettiwar and Asefa 2013).

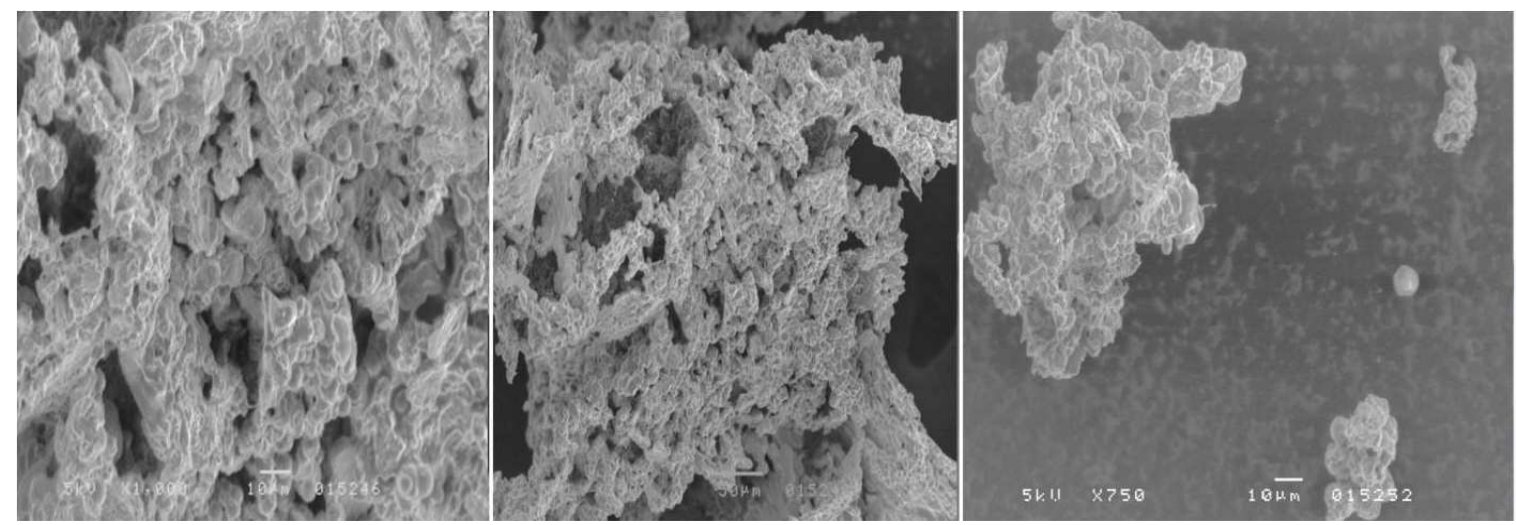

Figure 9 - Scanning electron photomicrographs of CHMS.

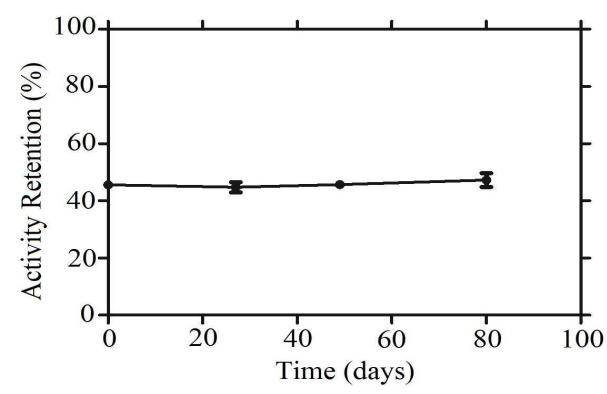

Figure 10 - Storage stability of CHMS derivatives at $4^{\circ} \mathrm{C}$.

\section{CONCLUSIONS}

This study developed methods of Cercospora kikuchii lipases immobilization on chitosan microparticles. Immobilization strategy was the most important factor to attain active and stable immobilized derivatives. Results also showed that some features in the chitosan structure (linkers for covalent attachment and groups for weak interactions) could greatly influence the enzyme attachment and might be the key for the success in the immobilization process. Pre-activated CAM was the best support due the high enzyme activity retention, easy recovery and reuse of the catalytic material. Thus, 
chitosan microparticles were potential support in $C$. kikuchii lipases immobilization technology for a wide range of industrial applications, mainly due the simplicity of the process involved in support production.

\section{ACKNOWLEDGMENTS}

The authors gratefully acknowledge the financial support of Fundação de Amparo à Pesquisa do Estado de São Paulo - FAPESP (Process no. 2011/00743-8).

\section{REFERENCES}

Barbosa O, Torres R, Ortiz C, Fernandez-Lafuente R. Versatility of glutaraldehyde to immobilize lipases: Effect of the immobilization protocol on the properties of lipase B from Candida antarctica. Process Biochem. 2012; 47: 1220-1227.

Betancor L, Lopez-Gallego F, Hidalgo A, AlonsoMorales N, Dellamora-Ortiz G, Mateo, C, FernandezLafuente R, Guisan JM. Different mechanisms of protein immobilization on glutaraldehyde activated supports: Effect of support activation and immobilization conditions. Enzyme Microbiol Technol. 2006, 30:877-882.

Biró E, Németh A, Sisak C, Feczkó T, Gyenis J. Preparation of chitosan particles suitable for enzyme immobilization. J Biochem Biophys Methods. 2008; 70:1240-1246.

Borges WS, Borges KB, Bonato PS, Said S, Pupo MT. Endophytic fungi: Natural products, enzymes and biotransformation reactions. Curr Org Chem. 2009; 13: 1137-1163.

Borgston B and Brockman HL. Lipases. 4th ed. Amsterdan: Elsevier; 1984.

Bradford MM. A rapid and sensitive method for the quantitation of microgram quantities of protein utilizing the principle of protein-dye binding. Anal Biochem. 1976; 72:248-254.

Bussamara R, Fuentefria AM, Oliveira ES, Broetto L, Simcikova M, Valente $\mathrm{P}$, et al. Isolation of a lipasesecreting yeast for enzyme production in a pilot-plant scale batch fermentation. Bioresource Technol. 2010; 101:268-275.

Castro HF, Anderson WA. Fine chemicals by biotransformation using lipases. Quim Nova. 1995; 18:544-554.

Castro HF, Mendes AA, Santos JC, Aguiar CL. Modificação de óleos e gorduras por biotransformação. Quim Nova. 2004; 27:146-156.
Costa-Silva TA, Cognette RC, Souza CRF, Said S, Oliveira WP. Spouted Bed Drying as a Method for Enzyme Immobilization. Drying Technol. 2013; 3:1756-1763.

Costa-Silva TA, Nogueira MA, Souza CRF, Oliveira WP, Said S. Lipase production by endophytic fungus Cercospora kikuchii: Stability of enzymatic activity after spray drying in the presence of carbohydrates. Drying Technol. 2011; 29:1112-1119.

Costa-Silva TA, Said S, Souza CRF, Oliveira WP. Stabilization of endophytic fungus Cercospora kikuchii lipase by spray drying in the presence of maltodextrin and $\beta$-cyclodextrin. Drying Technol. 2010; 28:1245-1254.

Dandavate V, Jinjala J, Keharia H, Madamwar D. Production, partial purification and characterization of organic solvent tolerant lipase from Burkholderia multivorans V2 and its application for ester synthesis. Bioresour Technol. 2009; 100:3374-3381.

Deive FJ, Carvalho E, Pastrana L, Rua ML, Longo MA, Sanroman MA. Strategies for improving extracellular lipolytic enzyme production by Thermus thermophilus HB27. Bioresource Technol. 2009; 100:3630-3637.

Dong Y, Xu C, Wang J, Wang M, Wu Y, Ruan Y. Determination of degree of substitution for $\mathrm{N}$ acylated chitosan using IR spectra. Sci China, Ser B: Chem. 2001; 44: 216-224.

Fernandez-Lafuente R, Rosell CM, Rodriguez V, Guisan JM. Strategies for enzyme stabilization by intramolecular crosslinking with bifunctional reagents. Enzyme Microbiol Technol. 1995; 17:517523.

Fernandes MRV, Costa-Silva TA, Pfenning LH, CostaNeto CM, Heinrich TA, Alencar S, et al. Biological activities of the fermentation extract of the endophytic fungus Alternaria alternata isolated from Coffea arabica L. Braz J Pharm Sci. 2009; 45: 677685.

Kaewthong W, Sirisansaneeyakul S, Prasertsan P, HKittikun A. Continuous production of monoacylglycerols by glycerolysis of palm olein with immobilized lipase. Process Biochem. 2005; 40: 1525-1530.

Kim MI, Kim J, Lee J, Jia H, Na HB, Youn JK, et al. Crosslinked enzyme aggregates in hierarchicallyordered mesoporous silica: A simple and effective method for enzyme stabilization. Biotechnol Bioeng. 2006; 96: 210-218.

Kimura IY, Goncalves JR, Affonso C, Stolberg J, Laranjeira MCM, Fávere VT. Efeito do pH e do tempo de contato na adsorção de corantes reativos por microesferas de quitosana. Polim: Cienc Tecnol. 1999; 9:51-57. 
Liu Y, Jia S, Wu Q, Ran J, Zhang W, Wu S. Studies of $\mathrm{Fe}_{3} \mathrm{O}_{4}$-chitosan nanoparticles prepared by coprecipitation under the magnetic field for lipase immobilization. Catal Commun. 2011; 12:717-720.

Mateo C, Palomo JM, Fernandez-Lafuente G, Guisan JM, Fernandez-Lafuente R. Improvement of enzyme activity, stability and selectivity via immobilization techniques. Enzyme Microbiol Technol. 2007; 40:1451-1463.

Mayordomo I, Randez-Gil F, Pietro JA. Isolation, purification, and characterization of a cold-active lipase from Aspergillus nidulas. J Agric Food Chem. 2000; 48(2):105-109.

Menoncin S, Domingues NM, Freire DMG, Oliveira JV, Di Luccio M, Treichel H, et al. Imobilização de lipases produzidas por fermentação em estado sólido utilizando Penicillium verrucosum em suportes hidrofóbicos. Cienc Tecnol Aliment. 2009; 29:440443.

Muzzarelli RAA. Immobilization of enzymes on chitin and chitosan. Enzyme Microbiol Technol. 1980; 2:177-184.

Muzzarelli RAA, Peter MG. Chitin Handbook. Grottammare:Atec; 1997.

Orrego CE, Valencia JS. Preparation and characterization of chitosan membranes by using a combined freeze gelation and mild crosslinking method. Bioprocess Biosyst Eng. 2009; 32:197-206.

Polshettiwar V, Asefa T. Nanocatalysis: Synthesis and Applications. 1st ed. New Jersey: John Wiley \& Sons, Inc.; 2013.

Rorrer GL, Hsien TY. Synthesis of porous-magnetic chitosan beads for removal of cadmium ions from waste water. Ind Eng Chem Res. 1993; 32: 21702178 .
Signini R, Campana Filho SP. Características e propriedades de quitosanas purificadas nas formas neutra, acetato e cloridrato. Polim: Cienc Tecnol. 2001; 11:58-64.

Simões AS, Mori RY, Faria R, Castro HF, Mendes AA. Desempenho da matriz híbrida $\mathrm{SiO}_{2}$-quitosana na imobilização da lipase microbiana de Candida rugosa. Quim Nova. 2011; 34:33-38.

Verger R. 'Interfacial activation' of lipases: Facts and artifacts. Trends Biotechnol. 1997; 15:32-8.

Vertegel AA, Siegel RW, Dordick JS. Silica nanoparticle size influences the structure and enzymatic activity of adsorbed lysozyme. Langmuir. 2004; 20: 6800-6807.

Verza M., Arakawa NS, Lopes NP, Kato MJ, Pupo MT, Said S, Carvalho I. Biotransformation of a tetrahydrofuran lignan by the endophytic fungus Phomopsis sp. J Braz Chem Soc. 2009; 20:195-200.

Vogel HJ. A convenient growth medium for Neurospora crassa. Microb Genet Bull. 1956; 13:4243.

Zhang DH, Yuwen LX, Peng LJ. Parameters Affecting the Performance of Immobilized Enzyme. J Chem. 2013; 2013:1-7.

Zhu J, Sun G. Lipase immobilization on glutaraldehyde-activated nanofibrous membranes for improved enzyme stabilities and activities. React Funct Polym. 2012; 72: 839-845. 